\title{
Legacies, socio-economic and biophysical processes and drivers: the case of future forest cover expansion in the Polish Carpathians and Swiss Alps
}

\author{
Bronwyn Price $^{1}$ (D) Dominik Kaim² ${ }^{2}$ Marcin Szwagrzyk $^{2} \cdot$ Katarzyna Ostapowicz $^{2}$ • \\ Natalia Kolecka ${ }^{2} \cdot$ Dirk R. Schmatz $^{1} \cdot$ Agnieszka Wypych $^{2} \cdot$ Jacek Kozak $^{2}$
}

Received: 30 June 2016/ Accepted: 4 November 2016/Published online: 17 November 2016

(C) The Author(s) 2016. This article is published with open access at Springerlink.com

\begin{abstract}
Mountain forest areas are key for providing a wide range of ecosystem services and are hot spots for land use change processes, in particular, increase in forest cover at the expense of mountain pastures and meadows. Mountain forest systems in eastern and western Europe have likely similar future socio-economic situations but significantly different socio-economic history. Using a scenario-based land use modelling approach (Dyna-CLUE framework) we model three scenarios (trend, liberalisation and self-sufficiency) of future land use in the Polish Carpathians and the Swiss Alps, focussing on forest cover change. We find that forest cover increase can be expected to continue in European mountainous regions under all likely scenarios, limited only by relatively strict policy interventions. Biophysical factors, rather than socio-economic ones, are key for defining the suitability for, and
\end{abstract}

Authors Bronwyn Price and Dominik Kaim contributed equally to this paper.

Electronic supplementary material The online version of this article (doi:10.1007/s10113-016-1079-z) contains supplementary material, which is available to authorized users.

\footnotetext{
Bronwyn Price

bronwyn.price@wsl.ch

Dominik Kaim

dkaim@gis.geo.uj.edu.pl

Marcin Szwagrzyk

mszwagrzyk@gis.geo.uj.edu.pl

Katarzyna Ostapowicz

kostapowicz@gis.geo.uj.edu.pl

Natalia Kolecka

nkolecka@gis.geo.uj.edu.pl

Dirk R. Schmatz

dirk.schmatz@wsl.ch
}

therefore likely locations of future forest cover, but land use legacy plays a very important role in the spatial patterns of future forest cover, particularly in eastern Europe.

Keywords Forest cover change $\cdot$ Land use change $\cdot$ Future scenarios - The Polish Carpathians - The Swiss Alps

\section{Introduction}

Mountain forest areas are key for providing a wide range of ecosystem services such as soil protection, water cycle regulation, habitat connectivity for large carnivores (Körner and Spehn 2002) and protection against landslides (Malek et al. 2015). At the same time, increase in forest cover in European mountain regions is generally at the expense of mountain agricultural areas, e.g. pastures and meadows, which are perceived as biodiversity hot spots (Pellissier et al. 2013) and crucial elements for landscape aesthetics and cultural value (Lindemann-Matthies et al. 2010). Mountainous areas are subject to substantial land use and cover change (LUCC) processes which also have

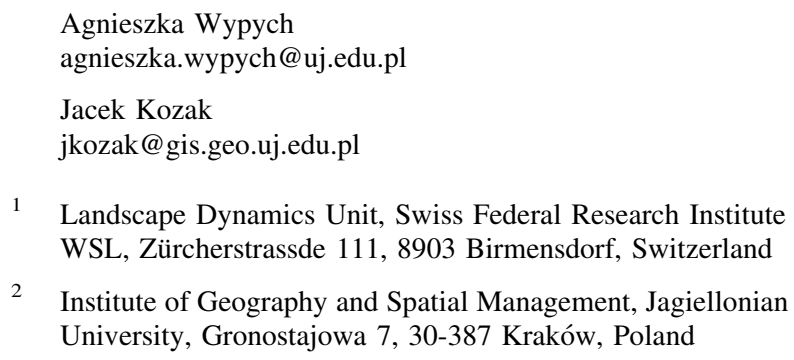
WSL, Zürcherstrassde 111, 8903 Birmensdorf, Switzerland

2 Institute of Geography and Spatial Management, Jagiellonian University, Gronostajowa 7, 30-387 Kraków, Poland 
critical implications for the lowlands such as supply of clean water (Viviroli et al. 2007).

Two major processes influence forest cover changes in mountainous regions in Europe. Firstly, abandonment of mountain agricultural land is now visible all across Europe, due to relatively low agricultural profitability (MacDonald et al. 2000; Gellrich et al. 2007; Pazúr et al. 2014; Kolecka et al. 2015), and this is a key LUCC driver in the appearance of new forest areas. Another facet of LUCC in mountainous areas relates to tourism and recreation activities, influencing the development of settlement and transport infrastructure and in some cases preventing forest regrowth on what would otherwise be abandoned land (Huzui et al. 2013). The second major process is climate change, which can cause an upward shift of the treeline and result in an increase in forest cover particularly in the tree line ecotone (Gehrig-Fasel et al. 2007).

LUCC visible at the continental scale indicates noticeable differences between the western and eastern part of Europe in the past (Levers et al. 2015; Kuemmerle et al. 2016) and with potential for such differences in the future (Verburg and Overmars 2009; Stürck et al. 2015). Kuemmerle et al. (2016) observe a clear divide in the patterns and intensity of agriculture, with lower intensity farming and hot spots of cropland decline in the east (including the Polish Carpathians). The relative stability of socio-economic processes in the west of Europe (Bürgi et al. 2015) is contrary to the rapid socio-economic changes and political shocks that have taken place in the eastern part of the continent over recent decades (Bičík et al. 2001; Munteanu et al. 2014; Affek 2015). Indeed, differences in socioeconomic and institutional factors are often considered more important in defining differences in LUCC patterns than biophysical conditions (Alcantara et al. 2012). In such comparisons, mountainous areas stand out as regions facing the most noticeable changes, for example due to postwar resettlements, such as in Czechia (Bičík et al. 2001), Slovenia (Mares et al. 2013) or Poland (Kozak et al. 2007).

As land use/land cover (LULC) in mountain areas is influenced by many interlinked natural and anthropogenic processes and a key component of global change, there is a strong need to assess likely and possible directions of the future transformation of the LULC mosaic in mountain areas. LUCC scenario models offer practitioners and policy makers the possibility to examine potential trajectories of change and base their assumptions and management strategies on the knowledge of what change is possible under certain conditions. However, although mountains are perceived as hot spots of land change processes (Verburg and Overmars 2009), and while several studies have examined LUCC scenarios in European mountains (Huber et al. 2013), little attention has been paid to comparison of future LULC scenarios for mountain areas located in the
Fig. 1 a Study area in the Polish Carpathians and the land use transitions resulting from the scenario modelling. b The study area in the Swiss Alps and the land use transitions resulting from the scenario modelling

western and eastern part of the continent. Comparisons of regions with a relatively similar bio-geographical context, and potentially similar future socio-economic situations [considering Poland can be thought of as being in the closing phases of the shift from socialism to marketeconomy (Jepsen et al. 2015)], but significantly different past socio-economic systems, not only assist in disentangling socio-economic and biophysical drivers of change, but in particular allow examining the importance of socioeconomic legacies.

Therefore, this research focuses on the two broad mountain ranges in Europe: the Swiss Alps, as an example of a western European mountain region, and the Polish Carpathians representing eastern Europe. The likely spatial patterns and magnitude of future LUCC, and in particular forest cover change until the mid-twenty-first century are examined. The research explores the importance of legacies and biophysical or socio-economic drivers of forest cover in the two mountainous regions.

\section{Methods}

\section{Study area}

The study area represents two separate mountainous regions within Europe, the Swiss Alps and the Polish Carpathians (Fig. 1a, b). The Swiss Alps are represented by the cantons of Glarus, Uri, Graubünden, Nidwalden and Obwalden altogether covering $9634 \mathrm{~km}^{2}$. The Polish part of the study area includes 194 communes recognised by the Carpathian convention and located totally within the Carpathians (Balon et al. 1995) covering 18,122 $\mathrm{km}^{2}$. Both mountainous regions have experienced forest transition (a shift from net forest loss to net forest gain) from the midlate nineteenth century (Mather and Fairbairn 2000; Kozak and Szwagrzyk 2016) although climatic conditions and altitudinal zonation differ between the areas. The Swiss Alps have experienced a relatively slow and steady increase in forest cover since the mid-nineteenth century, while the Polish Carpathians experienced a slow increase in forest cover in the nineteenth century and a rather rapid increase since the 1970s. Within the Swiss Alps, the highest elevations are within the nival zone, but only a small part of the Polish Carpathians (Tatra Mountains) reach the subnival belt. The topographic conditions also influence land use. In both regions the settlements are located mostly in the valleys but in the Carpathians 
(a) 2013

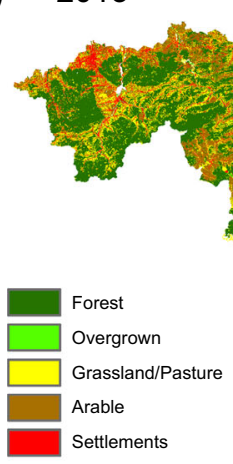

Transitions 2060: Liberalisation scenario

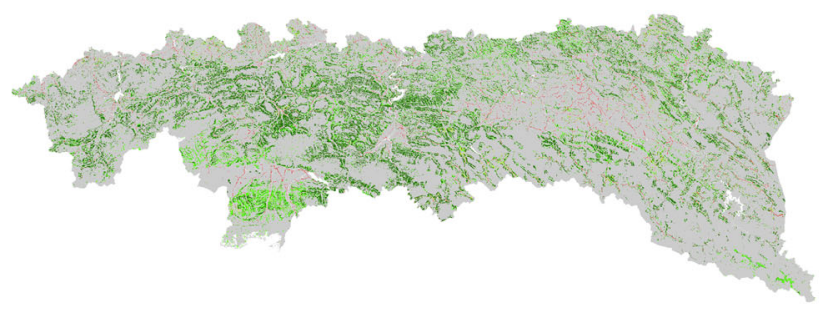

\begin{tabular}{llll}
$0 \quad 25 \quad 50$ & 100 \\
\hline & Kilometers
\end{tabular}

\begin{tabular}{lll}
$0 \quad 25 \quad 50$ & 100 \\
\hline & & Kilometers
\end{tabular}

(b) 2012

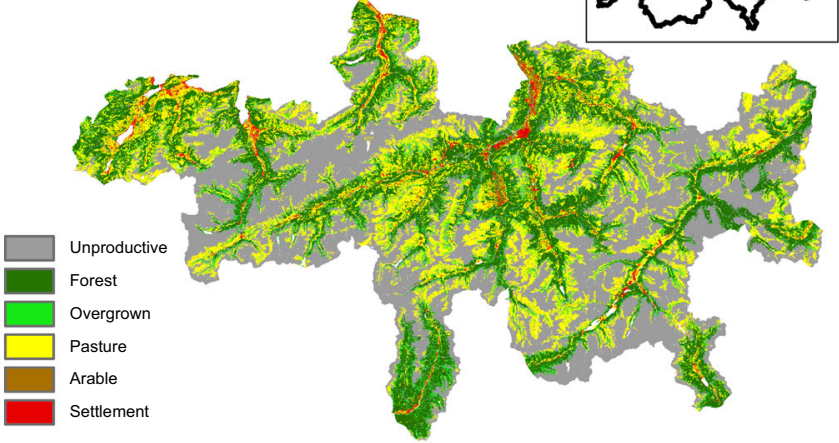

Transitions 2060: Liberalisation scenario

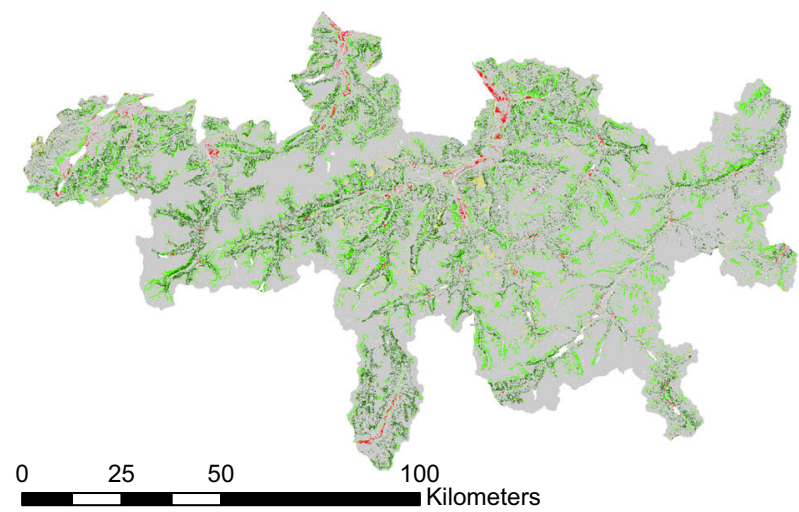

Transitions 2060: Trend scenario

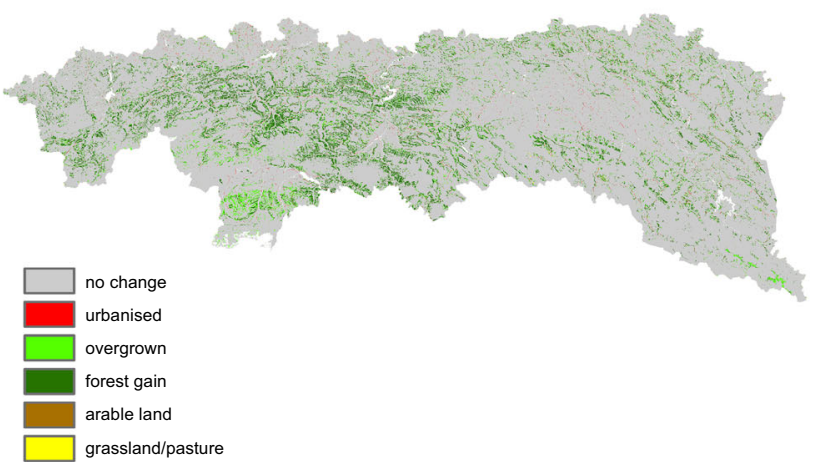

Transitions 2060: Self sufficiency scenario

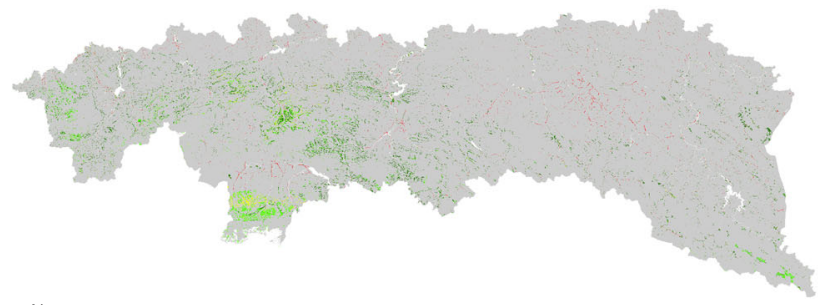

$\bigwedge^{N}$

Transitions 2060: Trend scenario

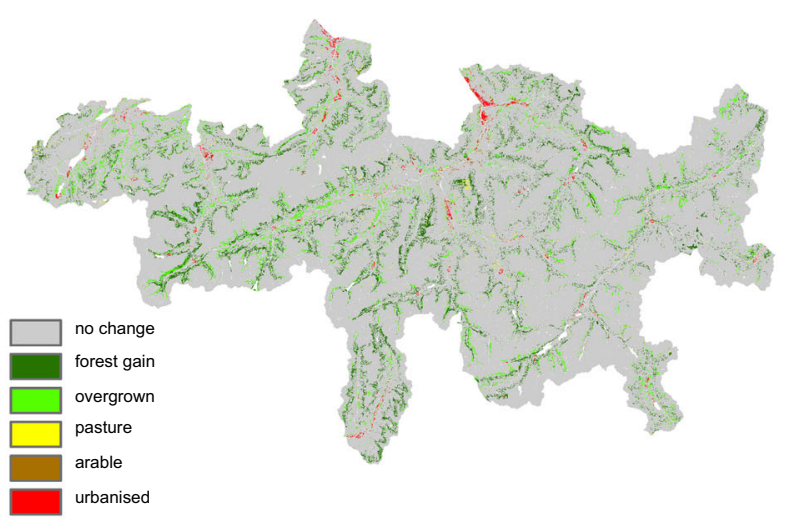

Transitions 2060: Self-sufficiency scenario

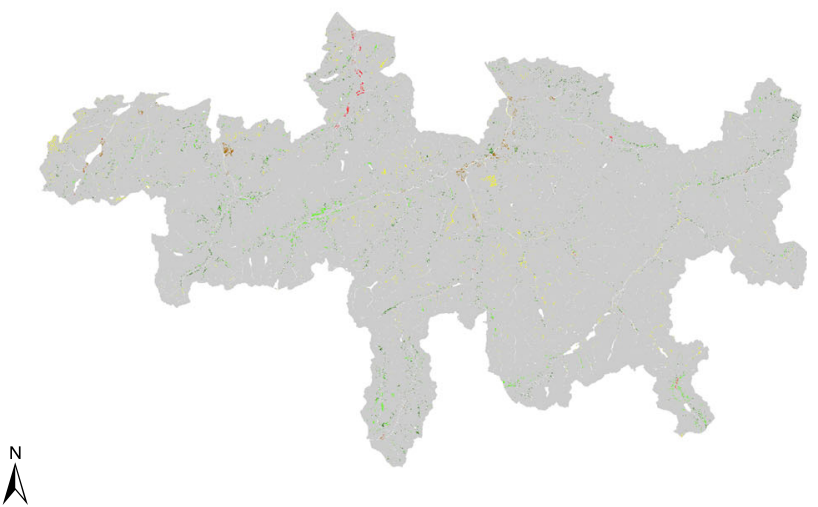


agricultural areas very seldom exceed $1000 \mathrm{~m}$ asl, while in the Swiss Alps pastures can be found at up to $2400 \mathrm{~m}$ asl (SFSO 2013). There are substantial differences between the study regions with respect to sociopolitical history. Switzerland has experienced a relatively stable economic and political situation over last decades. However, recent decades have been a period of political shifts and transition in Poland (Jepsen et al. 2015).

\section{Approach}

A scenario-based approach is used to investigate future land use change in the Swiss Alps and the Polish Carpathians with special consideration of future forest cover. Future land use is modelled with the land use allocation framework CLUE (conversion of land use and its effects), Dyna-CLUE version (Verburg and Overmars 2009). The initial state year (2012 for Switzerland and 2013 for Poland) was defined based on available data. Future land use at a 1-ha resolution was modelled in spatially explicit manner to the year 2060 based on suitability for current land uses; scenario defined future land use demands; socio-economic and biophysical driving forces; and spatial allocation procedures (see supplementary material for approach overview).

\section{Data}

\section{Forest cover and land use data: the Swiss Alps}

Forest cover was determined by the most recent (2012) digital topographical landscape model (TLM) of Switzerland (Swisstopo 2012). Other land use categories were derived from the Swiss land use/land cover statistics 2004-2009 time period (SFSO 2013). The Swiss land use statistics are regularly updated on a cycle and are available for three time periods 1979-1985, 1992-1997 and 2004-2009. We used the 2004-2009 period to represent the current land use. The available 72 categories of land use/land cover (SFSO 2013) have been aggregated into six land use classes: closed forest, overgrown areas, pasture agriculture, intensive agriculture, settlement and urban areas, and 'other', which includes unproductive vegetation and bare land as described in Table 1 and following Price et al. (2015) except that only water bodies are masked out as 'no data'.

Forest cover from the TLM was taken to be the most accurate representation of forest cover extent for the region since it is the most recent dataset and has a high accuracy (1-3 $\mathrm{m}$ for forest edges, Swisstopo 2012). Where there were discrepancies between that and the land use statistics data, TLM was considered to override the latter. Areas designated forest in the TLM but not in the land use statistics were defined as forest. Areas designated as forest in the land use statistics but not in the TLM were minimal and reassigned to be 'overgrown' since we assume they are not forest if not identified as such on the more accurate TLM, but likely some kind of woody or bushy vegetation at the point of the coarser aerial photo interpretation of the land use statistics.

\section{Forest cover and land use information: the Polish Carpathians}

Land use information for the Polish Carpathians was based on the national database of topographic objects for Poland (Baza Danych Obiektów Topograficznych; BDOT10k) valid for 2013. However, since forest information in the database was mostly based on land cover (aerial data interpretation) as opposed to land use, several modifications were implemented to include degraded coniferous forests under current forest management but with no tree cover as forest cover. These areas were identified using combined information from several other national agencies (incl. State Forests IT System (SILP) and Agency for Restructuring and Modernisation of Agriculture (ARiMR), Central Statistical Office (GUS) and visual interpretation of aerial imagery (Dobosz and Kozak 2015). Land use classes overgrown, grassland, intensive agriculture, and settlements, and other were aggregated based on the BDOT10k (Table 1). When there was a conflict with the modified forest mask, the priority was given to the forest mask. Classes 'other' and 'no data' were excluded from the modelling.

\section{Explanatory variables}

In both study areas suitability models for each land use type were developed based on a set of spatially explicit biophysical (including climatic) and socio-economic variables. The available data were reduced to a final set (Table 2) based on explanatory power in univariate linear regression and previous land use change modelling work (Price et al. 2015). For variable pairs with a cross-correlation coefficient higher than 0.7 only the variable with the higher explanatory power in the univariate linear regression was retained. Temperature and elevation were highly correlated (0.99 correlation coefficient) and as such elevation was removed and temperature retained as a dynamic variable. Due to the differences in the scope of available statistical data, not all variables were fully comparable between the Carpathians and the Alps (Table 2).

For forest cover and settlements, Dyna-CLUE's neighbourhood enrichment factor was calculated following Verburg et al. (2004a, b). Urban settlement is generally considered to develop in sprawling pattern with area close to 
Table 1 Class aggregation from Swiss land use statistics and Polish BDOT10k

\begin{tabular}{|c|c|c|}
\hline $\begin{array}{l}\text { Aggregated } \\
\text { class }\end{array}$ & Swiss land use statistics (2004 nomenclature) & The national database of topographic objects (BDOT10k) \\
\hline Forest & $\begin{array}{l}\text { Normal dense forest, forest strips, felling areas, damaged forest } \\
\text { areas, groves and hedges, clusters of trees, reforestations, } \\
\text { open forest on unproductive areas, brush forest, scrub } \\
\text { vegetation }\end{array}$ & Forest including damaged forest areas, copse, wooded area \\
\hline Overgrown & Brush meadows and farm pastures, brush alpine pastures & $\begin{array}{l}\text { Shrubs, small woodlots on meadows, pastures and other } \\
\text { abandoned agricultural lands }\end{array}$ \\
\hline $\begin{array}{l}\text { Pasture } \\
\text { agriculture }\end{array}$ & $\begin{array}{l}\text { Meadows, farm pastures, alpine meadows, favourable alpine } \\
\text { pastures, rocky alpine pastures, sheep pastures, open forest on } \\
\text { agricultural areas, clusters of trees on agricultural areas }\end{array}$ & Meadows, farm pastures, alpine meadows \\
\hline $\begin{array}{l}\text { Intensive } \\
\text { agriculture }\end{array}$ & $\begin{array}{l}\text { Arable land, intensive orchards, field fruit trees, vineyards, } \\
\text { horticulture }\end{array}$ & $\begin{array}{l}\text { Arable land, intensive orchards, field fruit trees, vineyards, } \\
\text { plantations, plant nurseries }\end{array}$ \\
\hline $\begin{array}{l}\text { Settlement } \\
\text { and urban }\end{array}$ & $\begin{array}{l}\text { Industrial and commercial buildings, surroundings of industrial } \\
\text { and commercial buildings, one and two family houses, } \\
\text { surroundings of one and two family houses, terraced houses, } \\
\text { surroundings of terraces houses, blocks of flats, surroundings } \\
\text { of blocks of flats, public buildings, surroundings of public } \\
\text { buildings, agricultural buildings, surroundings of agricultural } \\
\text { buildings, unspecified buildings, surroundings of unspecified } \\
\text { buildings, motorways, green motorway environs, roads and } \\
\text { paths, green road environs, parking areas, sealed railway } \\
\text { areas, green railways environs, airports, airfields green airport } \\
\text { environs, energy supply plants, waste water treatment plants, } \\
\text { other supply or waste treatment plants, dumps, quarries and } \\
\text { mines, construction sites, unexploited urban areas, public } \\
\text { parks, sports facilities, golf courses, camping areas, garden } \\
\text { allotments, cemeteries }\end{array}$ & $\begin{array}{l}\text { One and many family houses with surroundings, blocks of flats, } \\
\text { industrial and commercial buildings with surroundings, other } \\
\text { buildings, residential complexes, housing estates, transport } \\
\text { and communication areas, sport and recreational facilities, } \\
\text { parks, public complexes, hospital complexes, cemeteries, } \\
\text { camping areas, roads, railroads, airports, squares, garbage } \\
\text { dumps, excavation grounds, quarries and mines, other } \\
\text { industrial and storage areas }\end{array}$ \\
\hline Other & $\begin{array}{l}\text { Unproductive grass and scrubs, avalanche and rockfall barriers, } \\
\text { wetlands, alpine sports facilities, rocks, screes and sand, } \\
\text { landscape interventions, glaciers and perpetual snow }\end{array}$ & Mountain pine \\
\hline No data & lakes, rivers, flood protection structures & Water, rocks \\
\hline
\end{tabular}

existing settlement most likely to gain new settlements (Verburg et al. 2004a). Related work showed that distance to forest is by far the most important explanatory variable for predicting the occurrence of forest cover change in the past (Ostapowicz et al. 2015; Bolliger et al. this issue). DynaCLUE's neighbourhood function places a preferential weighting on pixels within the neighbourhood of a given land use, for allocation of new pixels of that land use type. The ability of these enrichment factors to predict new occurrences of settlement and forest was tested in a regression approach using land use change data for 1985-2009 (Switzerland) and 1970-2013 (Poland-for settlements 1970-2003 based on two communes as case studies (Szczawnica, Niedźwiedź)), where new (2000s) forest (or settlements) pixels represented the response variable and the enrichment factors for urban and forest cover were the explanatory variables. Enrichment factors were calculated for three neighbourhood sizes $(3 \times 3,5 \times 5$ and $7 \times 71$ ha pixels). The urban enrichment factor was not a significant explanatory variable for new urban areas in the Swiss Alps case study regions at any neighbourhood size, but it was very important for the Polish Carpathians, so it was used only in the Carpathian model. The forest enrichment factor, however, was found to be a significant explanatory variable for new forest cover (between 1985 and 2009 (CH)/1970-2013 (PL)) at all tested neighbourhood sizes in both regions, but with greatest explanatory power in a $3 \times 3$ neighbourhood of the 1 hectare data. In modelling of past changes in forest cover (Ostapowicz et al. 2015; Bolliger et al. this issue), distance to forest was found to be a significant driver at distances up to slightly more than $200 \mathrm{~m}$. Given the implementation of the Dyna-CLUE model is on an annual basis, we implemented only the enrichment factor for a $3 \times 3$ neighbourhood.

Climate scenario data was obtained from EURO-CORDEX (www.euro-cordex.net) for the representative concentration pathways (RCP) 4.5 and 8.5 derived from the GCM-RCM model chain MPI-M-MPI-ESM-LR (Global climate model), CLMcom-CCLM4-8-17 (Regional climate model), CLMcom (modelling group). These data were downscaled from 0.11 degree $(\sim 12 \mathrm{~km})$ resolution to a high resolution of $100 \mathrm{~m}$ using the change factor method (Anandhi et al. 2011) and the 30-year reference period 1961-1990 acknowledging the possibility of relative non- 
Table 2 Explanatory variables for land use suitability modelling

\begin{tabular}{|c|c|c|c|c|c|}
\hline \multirow[t]{2}{*}{ Variable } & \multicolumn{2}{|l|}{ Source } & \multicolumn{2}{|c|}{ Spatial resolution } & \multirow[t]{2}{*}{ Abbreviation } \\
\hline & $\mathrm{CH}$ & PL & $\mathrm{CH}$ & PL & \\
\hline \multicolumn{6}{|l|}{ Biophysical } \\
\hline \multicolumn{6}{|l|}{ Climate (dynamic) } \\
\hline Total summer precipitation & Euro-Cordex & Euro-Cordex & 1 ha & 1 ha & prec \\
\hline Summer average temperature & Euro-Cordex & Euro-Cordex & 1 ha & 1 ha & temp \\
\hline \multicolumn{6}{|l|}{ Relief (static) } \\
\hline Slope & DEM100 (SFSO 1992) & SRTM $90 \mathrm{~m}$ & 1 ha & 1 ha & slope \\
\hline Topographic Position Index & DEM100 (SFSO 1992) & SRTM 90 m & 1 ha & 1 ha & tpi \\
\hline \multicolumn{6}{|l|}{ Soil (static) } \\
\hline Soil permeability & $\begin{array}{l}\text { Soil suitability maps, } \\
\text { (SFSO 1992) }\end{array}$ & - & $\begin{array}{l}\text { Vector } \\
1: 200,000\end{array}$ & - & soil_p \\
\hline Soil stoniness & $\begin{array}{l}\text { Soil suitability maps, } \\
\text { (SFSO 1992) }\end{array}$ & - & $\begin{array}{l}\text { Vector } \\
1: 200,000\end{array}$ & - & soil_st \\
\hline Soil suitability for agriculture/forestry & $\begin{array}{l}\text { Soil suitability maps, } \\
\text { (SFSO 1992) }\end{array}$ & - & $\begin{array}{l}\text { Vector } \\
1: 200,000\end{array}$ & - & soil_suit \\
\hline \multicolumn{6}{|l|}{ Infrastructure/neighbourhood } \\
\hline $\begin{array}{l}\text { Neighbourhood enrichment factor (for } \\
\text { 'forest' and 'settlements') }\end{array}$ & $\begin{array}{l}\text { Swiss land use statistics } \\
\quad \text { (SFSO 2013) }\end{array}$ & $\begin{array}{l}\text { Ostapowicz et al. } 2015 \text {, } \\
\text { Dec et al. } 2009\end{array}$ & 1 ha & 1 ha & \\
\hline Distance to main roads (static) & $\begin{array}{l}\text { Swiss TLM (Swisstopo } \\
\text { 2012) }\end{array}$ & BDOT10k & - & $\begin{array}{l}\text { Vector } \\
1: 10,000\end{array}$ & dist_road \\
\hline \multicolumn{6}{|l|}{ Socio-economic } \\
\hline Population density (dynamic) & (SFSO 2010) & GUS & Municipality & Municipality & POP \\
\hline Average farm size & SFSO 2015 & GUS/BDOT10k & & & farm \\
\hline$\%$ of secondary homes & SFSO 2013 & - & & - & 2nd_home \\
\hline Hotels and pensions/10,000 inh. & - & GUS & & & tour \\
\hline Land ownership & - & State forest PL & & $\begin{array}{l}\text { Vector } 1: 10 \\
000\end{array}$ & owner \\
\hline
\end{tabular}

stationarity of overall patterns in highly heterogeneous landscapes at this resolution. For the Carpathians we used Carpatclim data (www.carpatclim-eu.org) as the reference dataset statistically downscaled to the resolution of 0.001 degree. To create the $0.1^{\circ}$ resolution gridded Carpatclim data 38 temperature and 102 precipitation stations within the Polish Carpathians, plus 17 and 48 stations respectively from neighbouring countries were used, which is the best coverage for the area to date. Carpatclim uses the MISH method for interpolation (Szentimrey et al. 2007). The high-resolution reference data set for the Swiss Alps was a spatial subset of the Swiss-wide data which was created using the daymet algorithm (Thornton et al. 1997) to interpolate the data of all available weather stations (annual average of $\sim 120$ temperature stations and $\sim 400$ precipitation stations in Switzerland between 1961 and 1990) of the Federal Office of Meteorology and Climatology (www. meteoswiss.admin.ch) over a $100 \mathrm{~m}$ elevation model (www.swisstopo.admin.ch). Finally, seasonal average temperature and precipitation sums were calculated for both study regions.
Socio-economic variables included population density, average farm size, the proportion of private dwellings that are secondary homes (as opposed to primary homes) (Switzerland) and the number of hotels per 10,000 inhabitants (Poland) as well as land ownership [Poland: private $(0)$ versus land owned by state forests (1)]. Current population data per commune came from the Swiss Federal Statistical Office (SFSO) and the Central Statistical Office of Poland (GUS). Future values of population were determined from SFSO population growth scenario models (SFSO 2010) and from GUS population projections (GUS 2014). Since the future scenarios are not spatially resolved to the commune level (the spatial resolution of the Swiss scenarios is the Canton to 2045 and the whole of Switzerland to 2065; for Poland the projections are available for poviats - NUTS4 level to 2050), an assumption was made that each commune would retain its relative proportion of the population from the 2012 level into the future for both study areas. A similar assumption was made with respect to average farm size and percentage of second homes per commune. The missing 2050-2060 period for Poland was filled in by sustaining the 2050 projections value to 2060 . 
In the Polish Carpathians, there are frequently substantially contrasting socio-economic properties between bordering rural and urban municipalities, and the aggregation of the socio-economic data to the spatial unit of the municipality results in significant discontinuity of future land use maps at these municipality borders, as an artefact of the dataset construction. To avoid these issues, all the socio-economic data in the Polish Carpathians were subject to smooth pycnophylactic interpolation, which results in smoothing the surface without changing the total value within the spatial unit (Tobler 1979), prior to modelling. Such contrasts were not visible in the Swiss modelling results, and here the interpolation was not conducted.

\section{Suitability modelling}

The probability of the presence of each land use type was modelled using binomial generalised linear modelling (GLM) with the explanatory variables described above (Table 2) (Verburg et al. 2004b). For each land use type and each region, approximately $10 \%$ of the total sample points were randomly sampled (where the total sample is all $100 \mathrm{~m}$ land use map pixels), reducing spatial autocorrelation by maintaining a minimum $1 \mathrm{~km}$ distance between sample points (Dungan et al. 2002). All combinations of the explanatory variables were modelled for each land use type and region and the final model was selected as the set of variables with the best AIC fit (Akaike 1973). Model averaging (the sum of Akaike weights over all models) (Burnham and Anderson 2002) was used to determine the relative importance of each explanatory variable per region and land use type. The R version 3.0.1 (www.r-project.org) packages multi-model inference (MuMIn), GLM and PS Imago SPSS 23 were used to fit the models. Area under the receiver operating curve (AUC) (Pontius and Schneider 2001) was used to determine the explanatory power of the models, comparing the modelled probability of a given land use to the actual land use map outside of the sample point locations. The maps of probability of a given land use presence resulting from the glm modelling as described above were used as proxies for suitability for that land use and input into the Dyna-CLUE modelling.

\section{Scenario development}

Climate, demography, economy and governance can be considered key driving forces for land use change in European mountainous regions (Hersperger and Burgi 2009). Three scenarios of future land use demands and forest cover were defined taking into account uncertainty in the trajectories of these driving forces. A story and simulation approach (Alcamo 2008) was used to develop the scenarios. A trend scenario and two scenarios defined along two axes: planning and policy intervention versus market orientation and globalisation versus regionalisation.

\section{Scenario descriptions}

The trend scenario was based on linear projection of observed land use trends. A linear interpolation of observed changes was also conducted to obtain land use demand for the year 2060. The liberalisation scenario assumes high global economic growth and population growth, a marketdriven economy with little or no policy intervention. This scenario is associated with stronger climate change trends and a greater rise in greenhouse gas emissions. No constraints on construction of new settlements or farm size are taken into account. It is also assumed that there is a low support for agricultural and conservation subsidies and less willingness to pay higher prices for local products. In the self-sufficiency scenario, the role of regional level development with an emphasis on self-sufficiency is crucial. Ecological awareness is much higher than in other scenarios. Local investment and immigration occur as part of the development of regional centres resulting in economic and population growth in the study regions. There is a willingness to pay for conservation, which includes conservation of the current cultural agriculture based landscapes and agricultural subsidies and tourism is supported to encourage regional growth. Moderate climate change and greenhouse gas emissions pathways are associated with this scenario.

\section{Scenario quantification}

Trend Within the Swiss study region the trend scenario was defined from linear projection of the observed land use changes from the period 1985 to 2009, according to the Swiss land use statistics (SFSO 2013). Historical, spatially explicit land use information was available within the Polish Carpathians for forest only. A 1970s forest mask, comparable with the mask created by Dobosz and Kozak (2015), was extracted automatically from 1970s Polish topographic map $(1: 25,000)$ for the whole study area (Jagiellonian University and Warsaw University of Technology 2016). The trend scenario in the Polish Carpathians was based on the sustaining the annual rate of forest change observed since the 1970s to 2013 (0.47\%, (Jagiellonian University and Warsaw University of Technology 2016; BDOT10k 2013) into the future. Another approach was used for the other land use trends in Poland since historical data were not available. For settlements, the projections were based on an assumption of $5 \%\left(436-458 \mathrm{~m}^{2} \mathrm{pp}\right)$ increase of the per capita urban demand, from the 2013 value in accordance with observed European lifestyle change trends (Jaeger and Schwick 2014). To determine 
settlement area, this per capita urban demand was multiplied by the projected number of inhabitants in each commune (GUS 2014). If population levels for a given commune are projected to decrease at any point in the modelling time span, the settlement area remains as the maximum inhabitant number multiplied by the per capita urban demand. Arable land and grassland make up the remainder of the land use demands, and it is assumed that the 2013 proportions between them will be maintained.

Liberalisation and self-sufficiency Demand for forest area and overgrown area are defined as a joint demand and equal to the remaining areas, once demand for urban and agricultural areas are taken into account. However, in consideration of climate change and potential for areas currently considered unproductive to become suitable for forest cover under different temperature or rainfall conditions, an additional 'demand' for forest area is included in Switzerland in both the liberalisation and self-sufficiency scenarios. The area of this 'demand' is calculated by defining the observed threshold of precipitation and temperature that forest currently appears at and then calculating the area of 'scrub vegetation' and 'unproductive grass and scrub' that will fall above this threshold by 2060 considering the climate change scenarios relevant to each of our storylines (RCP 4.5 for self-sufficiency and 8.5 for liberalisation). The demand value for potential new forest area is also checked with the area of observed changes between 1985 and 2012 from 'scrub vegetation' and 'unproductive scrub and shrubs' to 'forest' or 'overgrown'. This 'demand' for new forest is added to the total demand for forest area in each scenario, and the spatial allocation component of Dyna-CLUE spatially distributes this total demand across all areas of the study area suitable for forest. Since in the Polish part of the study area the area of equivalently high elevation areas is negligible, this additional forest demand is not applied in the Polish study region.

In the Swiss study region population growth scenario models developed by the Swiss Federal Statistical Office (SFSO) provide the basis for urban and settlement demand in the liberalisation and self-sufficiency scenarios (SFSO 2010). Economic development and immigration are incorporated into the three SFSO modelled population growth scenarios-'low', 'medium' and 'high'. To calculate a total urban area demand per scenario, we used the modelled population level for 2060 in combination with the minimum and maximum of current per capita urban area demand data for the five cantons in our study area. For the self-sufficiency scenario, the low population growth SFSO scenario and minimum urban area demand $\left(454 \mathrm{~m}^{2}\right.$ per person) was used, for the liberalisation scenario the high growth SFSO scenario and maximum urban area demand $\left(646 \mathrm{~m}^{2} \mathrm{pp}\right)$. Similarly in the Polish study region the area of settlement also depends on the projected number of inhabitants according to the GUS population projection 2013-2050 (GUS 2014). Since there is only one population projection available (no scenarios), the projection is the same for the liberalisation and self-sufficiency scenarios in Poland. The per capita urban demand remains the same as in $2013\left(436 \mathrm{~m}^{2} \mathrm{pp}\right)$ in the self-sufficiency scenario and increases by $6 \%\left(462 \mathrm{~m}^{2} \mathrm{pp}\right)$ in the liberalisation scenario.

Agricultural area demand is based on current trends, findings from the literature and our storylines. According to Rounsevell et al. (2005), given advances in technology, under all SRES scenarios (IPCC Special Report Emissions Scenarios), we can expect an oversupply of agricultural land in Europe by 2040 in the range of 9-25\%, depending on scenario. However, a rather more moderate trend has been observed for Switzerland between 1985 and 2009 of a $5.4 \%$ decrease in agricultural land (SFSO 2013). In the Polish Carpathians, a decrease in agriculture has also been observed over the last decades (Munteanu et al. 2014). For instance in Szczawnica-one of the typical mountain communes, $31 \%$ of agricultural lands is currently experiencing secondary forest succession (Kolecka et al. 2015). Agricultural land decreased by almost $20 \%$ in Poland between 1998 and 2011 (FAO 2015). Agricultural area in the Swiss part of the study area is predominantly pasture, while in the Polish Carpathians grasslands and arable lands occupy similar areas. It is assumed the relative breakdown between pasture and arable agriculture will remain as in the past. Technological advances allow more intensive agriculture in each scenario (Rounsevell et al. 2005; EEA 2007; Kopainsky et al. 2013).

In the liberalisation scenario agricultural activity depends mostly on the market economy and potential profitability. The liberalisation scenario sees a loss of agricultural land in Switzerland at the rate of approximately $1 \%$ per year due to lack of support for agricultural subsidies and low population. In Poland the forest cover increase in the liberalisation scenario is defined as $+0.6 \%$, comparable to past observations in the Carpathians for high forest cover dynamics, but lower than forest cover increase triggered by shock conditions such as resettlement actions (Kozak 2010).

Under the self-sufficiency scenario, the protection of landscape and biodiversity is perceived as an important factor influencing land use and supported by policy interventions. The self-sufficiency scenario requires maintaining the current area of agricultural land (Kopainsky et al. 2013), and, with support for subsidies and regional development, as a result both grassland and arable land will occur not only on the most suitable areas, but also in the higher and less optimal locations. A low $(+0.15 \%)$ forest cover increase is expected in Poland for the self-sufficiency 
scenario, as observed in Carpathians regions with stable socio-economic situation in the past (Kozak 2010).

A matrix of allowed land use class conversions was defined per scenario. Conversion to overgrown from intensive agriculture and pasture agriculture was permitted for the trend and liberalisation scenarios, and in Switzerland restricted below $1200 \mathrm{~m}$ in elevation for the selfsufficiency scenario to account for increased agricultural subsidies but permitted at higher elevations where agriculture is more marginal. Only overgrown areas and the unproductive areas classified as scrub vegetation or unproductive grass and shrubs may be converted to forest (to represent natural forest succession). In the case of overgrown areas, there is an automatic conversion to forest after a given time lag. Depending on elevation, time lags for succession from overgrown to forest were applied: 15 years at $<1200 \mathrm{~m}$ asl, 30 years at $1200-1600 \mathrm{~m}$ asl, 45 years at $>1600$ in the Alps (Tasser et al. 2007) and 15 years at $<700 \mathrm{~m}$ asl, 30 years at $700-1100 \mathrm{~m}$ asl, 45 years at $>1100$ in the Carpathians (Ciurzycki 2004; Szewczyk et al. 2011; Tokarczyk 2013). However, above $2000 \mathrm{~m}$ asl in Switzerland (1600 m in Poland) forest succession was only possible on given land use types (scrub vegetation and unproductive grass and shrubs), and with climate change improving suitability for forest cover. In the self-sufficiency scenario conversion to settlement areas was only permitted within areas currently zoned for building for Switzerland and to the surroundings of the existing settlements (by defining more strict neighbourhood power in the model) in Poland. Settlement development was not possible within national parks. All other conversions were allowed.

\section{Results}

For almost all land use classes and in both regions, biophysical variables were more important than socio-economic variables in determining land use type, and in particular, slope and climate were always important (Table 3). However in Poland, distance to roads and land ownership (State Forests lands versus private ownership) were very important variables for a number of land use classes. This is an indicator of the importance of the socioeconomic difference between the two study regions, but also of the biophysical differences since, considering higher elevations in the Swiss Alps, some variables will be more limiting there than in the Polish Carpathians. Variables that can be considered to be indicative of touristic development, i.e. percentage of second homes (Switzerland) and number of hotels (Poland), had a positive relationship to cover of forest and overgrown areas. Farm size was related positively to settlement and forest area
(Switzerland) and negatively to presence of agriculture, reflecting that larger farm sizes usually mean greater intensity of agriculture but perhaps less agricultural area with abandoning of smaller pastural farms and increased forest cover (Gellrich et al. 2007).

There was a much clearer overall spatial pattern in the distribution of the predicted changes in land use across the study regions, particularly forest cover, in Poland than in Switzerland (Fig. 1a, b). All the scenarios projected new forest areas to be located rather in the central and western part of the Polish study region than in the eastern part. In the Swiss study region, there was a relatively even spread of forest gain (as per the scenario definitions there was no forest loss under any scenario in Switzerland and in Poland) across the whole study region.

In the Polish Carpathians, the projected forest cover of the study area for 2060 was modelled as $58 \%$ (16\% increase from 2013) for trend, $61 \%$ (22\% increase) for liberalisation and 53\% (5\% increase) for self-sufficiency scenario, in the Swiss Alps 30.1\% (25.4\% increase from 2012 cover), $32.6 \%$ (36\% increase) and $24.5 \%$, respectively, (2.4\% increase). The forest increase in the Swiss study region was largely the result of agricultural abandonment processes in the trend and liberalisation scenarios with 62.8 and $81 \%$ of the new forest areas being converted from overgrown or agricultural areas, respectively. The remaining new forest occurred in areas of 2012 scrub and unproductive grass and shrub land. However, due to assumptions within the scenario definition, in the self-sufficiency scenario, $99 \%$ of the new forest areas occurred in areas that were previously scrub or unproductive grass and shrub and could be considered the result of changes in suitability for forest with climate changes. The total amount of forest gain was low in this scenario (5375 ha). Potential overgrown areas were located mainly in the proximity of the forest edge (Fig. 1a, b); however, there were substantial differences in terms of the area modelled among scenarios in both study areas. For the trend scenario, the overgrown area was estimated as $3.2 \%$ of the Polish study region, while in the liberalisation scenario it was $5.4 \%$. In the self-sufficiency scenario, by contrast, it was $1 \%$. In the Swiss study area overgrown covered 8.5, 11.5 and $8.8 \%$, respectively. In the Polish study region, the location of the overgrown areas within the Podhale region-a foothill zone located north of the Tatra Mountains, characterised by relatively high elevation (around $1000 \mathrm{~m}$ asl) for Carpathian conditions (Fig. 1a), was common across the scenarios. Both arable lands and grassland declined in all the scenarios for the Polish study area, but in the self-sufficiency scenario, a substantial part of the current arable lands was converted to grasslands in the above-mentioned Podhale region, in contrast to other scenarios, where those areas were converted into 
Table 3 Explanatory power of each modelled land use class and five most important explanatory variables with relative importance in brackets, where + is a positive response and - a negative response

\begin{tabular}{|c|c|c|c|c|}
\hline \multirow{2}{*}{$\begin{array}{l}\text { Land use } \\
\text { class }\end{array}$} & \multirow{2}{*}{$\begin{array}{l}\text { Explanatory } \\
\text { power AUC } \\
\text { Poland }\end{array}$} & \multicolumn{3}{|c|}{ Five most important variables in order (see Table 2 for definition) } \\
\hline & & Switzerland & Poland & Switzerland \\
\hline Forest & 0.823 & 0.870 & $\begin{array}{l}\text { temp- }(1), \text { slope }+(1), \text { prec- }(1), \text { dist_road }+(1), \\
\text { tour }+(0.88)\end{array}$ & $\begin{array}{l}\text { soil_suit- (1), slope+ }+(1), \text { temp }+(1), \text { prec- } \\
(1), \text { farm }+(0.61)\end{array}$ \\
\hline Overgrown & 0.744 & 0.697 & $\begin{array}{l}\text { prec }+(1), \text { slope- }(1), \text { dist_road- }(1), \text { temp }+(1), \\
\text { owner- }(0.98)\end{array}$ & $\begin{array}{l}\text { soil_suit- }(1), \text { temp }+(1), \text { slope }+(0.98), \text { pop- } \\
(0.95), 2 \text { nd_home }+(0.8)\end{array}$ \\
\hline $\begin{array}{l}\text { Grassland/ } \\
\text { Pasture }\end{array}$ & 0.647 & 0.800 & $\begin{array}{l}\text { dist_road- }(1), \text { slope- }(1) \text {, prec }+(1), \text { temp }+ \\
(0.97) \text {, owner }+(0.88)\end{array}$ & $\begin{array}{l}\text { soil_suit- (1), slope- (1), temp- (1), prec+ } \\
(1) \text {, farm- (1) }\end{array}$ \\
\hline $\begin{array}{l}\text { Intensive } \\
\text { agriculture }\end{array}$ & 0.746 & 0.985 & $\begin{array}{l}\text { slope- }(1), \text { tour- }(1), \text { farm- (1), dist_road- (1), } \\
\text { temp+ }(0.96), \text { prec- }(0.96)\end{array}$ & $\begin{array}{l}\text { temp+ }(1), \text { slope- }(1), \text { prec- }(1), \text { tpi+ }(0.92) \\
\text { soil_suit }+(0.29)\end{array}$ \\
\hline Settlement & 0.816 & 0.946 & $\begin{array}{l}\text { temp }+(1), \text { slope- }(1), \text { prec }+(1), \text { dist_road- }(1), \\
\text { tour- }(0.6)\end{array}$ & $\begin{array}{l}\text { slope- }(1), \text { temp }+(1), 2 \text { nd_home }+(1), \\
\text { soil_suit- }(0.99), \text { farm }+(0.67)\end{array}$ \\
\hline
\end{tabular}

overgrown. In the Swiss study region, pasture decreased in all scenarios but arable land increased in the self-sufficiency scenario, the spatial distribution, however, was very similar across all the scenarios.

New settlement areas were rather uniformly distributed across both regions of the study area in all the scenarios, and in both Switzerland and Poland, most of the projected settlement areas were located within foothill zones rather than higher mountains (Fig. 1). The area of settlements in the Polish study region for the trend scenario was projected as $6.8 \%$ (9\% increase from 2013), and under the liberalisation scenario $7.1 \%$ (14\% increase). Self-sufficiency has the lowest settlement projection at $6.6 \%$ (6\% increase). In the Swiss study region, settlement area covered $2.6 \%$ (24.6\% increase), $2.7 \%$ (27.6\% increase) and $2.1 \%(1.9 \%$ increase) of the study area respectively.

\section{Discussion and conclusions}

The results of the suitability modelling generally suggest that biophysical variables have greater explanatory power than the socio-economic variables for the presence of forest (and other land use types) in both our study regions. The importance of ownership for overgrown areas in Poland shows that the land abandonment happens largely on private land, which may substantially increase forest cover regardless of the afforestation plans made by State Forests, demonstrating the need for holistic land use management regardless of tenure. The influence of the biophysical variables might lead towards the thinking that the socioeconomic differences between the Swiss and the Polish study areas are not so important in understanding the likely future patterns of forest cover. However, here it is important to note the limitations of the modelling process. Socioeconomic processes and political changes are difficult to predict and capture with data that is suitable for spatially explicit modelling such as employed in this study (Aspinall and Hill 2007). The available data is unlikely to adequately characterise the socio-economic processes at play in forest cover modelling. Since we did not have population scenarios available at the spatial resolution of the commune, our necessary assumption that the spatial distribution of relative proportions of population will remain the same till 2060 limits the dynamism of our socio-economic variables into the future and potentially dampens spatial variability within the study region. Indeed the spatial resolution of the municipality can be considered coarse for land use change, and it would be important to examine sensitivity of the model results to this spatial rendering of the explanatory variables before interpreting results at a finer resolution.

The socio-economic and political differences between our study regions also influence the availability and extent of environmental monitoring and data. Many environmental and socio-economic data were collected in a similar, comparable manner over recent decades in Switzerland, while in Poland, the political transition period has influenced the manner and range of data collection, making long-term monitoring initiatives more difficult, and data equivalence between the two study regions challenging. In particular, in Poland no historical spatial data were available in digital format for land use classes other than forest. This influences the ability to build comparable scenarios and the evidence base for determining future demands.

The approach assumes that the important drivers of land use suitability will remain the same into the future. However, as related work in the study regions has shown, there can be significant differences in the drivers over time, particularly in the cases of political and socio-economic upheaval (Ostapowicz et al. 2015). For example, in the Swiss Alps land abandonment is reported as slowing in some studies, since most marginal land has already been abandoned (Hofer et al. 2014). In the Polish Carpathians, 
land abandonment estimates are $14 \%$ of the available agricultural area, yet the process clearly accelerated in the last two decades (Kolecka et al. 2015). It is difficult to predict whether and when a similar saturation level as in the Swiss Alps will be reached. Recent work has shown a clear difference in agricultural extent and intensity between eastern and western Europe over recent decades, with lower intensity and declining cropland extent in the east (Kuemmerle et al. 2016). As such processes change so too might the drivers of suitability for land use classes such as pasture or overgrown areas.

Under climate change, the Swiss Alps will experience potential upward shift of the treeline (Gehrig-Fasel et al. 2007). The occurrence of new forest on areas of scrub and unproductive grassland and shrubs generally above the 2012 treeline was minor in comparison with the gains on abandoned agricultural land but nevertheless significant under both the trend and the liberalisation scenarios, which featured the stronger climate change scenario (RCP 8.5). This is in line with previous work determining forest ingrowth from upward shift in Swiss mountainous areas (Gehrig-Fasel et al. 2007). This likely upward shift will also have implications for biodiversity and habitat change, as well as other ecosystem services, in particular carbon sequestration (Greenwood and Jump 2014).

Forest cover is increasing in European mountainous regions and can be expected to continue to increase regardless of development scenario. The modelling shows that for all future scenarios and in both the Polish Carpathians and the Swiss Alps an increase of forest area can be expected, and only with relatively strict policy interventions under the self-sufficiency scenario will forest expansion onto agricultural land be limited. This forest expansion will occur for the most part at the expense of agricultural area, in particular pasture. There are important implications for the management of mountainous areas especially with respect to aesthetic value, tourism and mountain biodiversity, which is being threatened by encroachment (Koch et al. 2015). The spatially explicit predictions in this work allow identification of areas most likely to be at risk of abandonment and forest ingrowth to target for management activities.

A key difference between the future scenarios for Poland and Switzerland is the location of the new forest areas. While in Switzerland new forest is spread across the study area in every scenario, in Poland new forest appears largely in the central and western part of the Carpathians. This is likely the result of the land use legacies. The eastern part of the Polish Carpathians has faced rapid forest gain following post-war depopulation with current forest cover at approximately $72 \%$ (Kozak et al. 2007; Ostapowicz et al. 2015). Most areas suitable for forest have already succumbed to forest succession, while in the western and central part of the Polish Carpathians there are still agricultural lands located in areas with similar conditions and suitability for forest. This is one of the many examples on the importance of historical land use legacies for future land use over long periods (Foster et al. 2003; Gimmi et al. 2013; Munteanu et al. 2015). However, in the absence of future socio-economic shocks, and given the importance of biophysical drivers demonstrated in this study, we envisage that forest cover trends in Poland would exhibit similar trends to those observed in Switzerland.

Acknowledgements Research carried out within the FORECOM project (Forest cover changes in mountainous regions-drivers, trajectories and implications, PSRP 008/2010), supported by a grant from Switzerland through the Swiss contribution to the enlarged European Union.

Open Access This article is distributed under the terms of the Creative Commons Attribution 4.0 International License (http://crea tivecommons.org/licenses/by/4.0/), which permits unrestricted use, distribution, and reproduction in any medium, provided you give appropriate credit to the original author(s) and the source, provide a link to the Creative Commons license, and indicate if changes were made.

\section{References}

Affek A (2015) Spatially explicit changes in land ownership through 3 socio-political systems: a case study from southeast Poland. Geogr Pol 88:519-530. doi:10.7163/GPol.0032

Akaike H (1973) Information theory and an extension of the maximum likelihood principle. In: Petrov BN (ed) Second international symposium on information theory. Akad. Kiadó, Tsahkadsor, Armenia, USSR, pp 267-281

Alcamo J (2008) Chapter six the SAS approach: combining qualitative and quantitative knowledge in environmental scenarios. Dev Integr Environ Assess 2:123-150

Alcantara C, Kuemmerle T, Prishchepov AV, Radeloff VC (2012) Mapping abandoned agriculture with multi-temporal MODIS satellite data. Remote Sens Environ 124:334-347. doi:10.1016/j. rse.2012.05.019

Anandhi A, Frei A, Pierson DC, Schneiderman EM, Zion MS, Lounsbury D, Matonse AH (2011) Examination of change factor methodologies for climate change impact assessment. Water Resour Res. doi:10.1029/2010WR009104

Aspinall RJ, Hill MJ (2007) Land use change: science, policy and management. CRC Press, Boca Raton

Balon J, German K, Kozak J, Malara H, Widacki W, Ziaja W (1995) Regiony fizycznogeograficzne Polskich Karpat. In: Warszyńska J (ed) Karpaty Polskie. Przyroda, czlowiek i jego dzialalnosc, Uniwersytet Jagiellonski, Krakow, pp 117-130

Bičík I, Jeleček L, Štěpánek V (2001) Land-use changes and their social driving forces in Czechia in the nineteenth and twentieth centuries. Land Policy 18:65-73. doi:10.1016/S0264-8377(00)00047-8

Bürgi M, Salzmann D, Gimmi U (2015) 264 years of change and persistence in an agrarian landscape: a case study from the Swiss lowlands. Landsc Ecol 30:1321-1333. doi:10.1007/s10980-015$0189-1$

Burnham KP, Anderson DR (2002) Model selection and multi-model inference: a practical information-theoretic approach, 2nd edn. Springer, New York 
Ciurzycki W (2004) Struktura przestrzenna naturalnych odnowień świerkowych na górnoreglowych polanach popasterskich w Tatrach Polskich. Sylwan 148:20-30

Dec M, Kaszta Ż, Korzeniowska K, Podsada A, Sobczyszyn-Żmudź S, Wójtowicz A, Zimna E, Ostapowicz K (2009) Zmiany użytkowania ziemi w trzech gminach Karpackich (Niedźwiedź, Szczawnica i Trzciana) w drugiej połowie XX wieku. Arch Fotogram Kartogr i Teledetekcji 20:81-98

Dobosz M, Kozak J (2015) Problem integracji danych przestrzennych na przykładzie szacowania współczesnej powierzchni lasów w Karpatach Polskich, XXV konferencja PTIP. Warsaw, Biblioteka Narodowa, 5-6 November 2015

Dungan JL, Perry JN, Dale MRT, Legendre P, Citron-Pousty S, Fortin MJ, Jakomulska A, Miriti M, Rosenberg MS (2002) A balanced view of scale in spatial statistical analysis. Ecography (Cop) 25:626-640. doi:10.1034/j.1600-0587.2002.250510.x

EEA (2007) Land-use scenarios for Europe: qualitative and quantitative analysis on a European scale (PRELUDE)

FAO (2015) FAOStat Agri-environmental indicators. http://faostat3. fao.org. Accessed 24 June 2016

Foster D, Swanson F, Aber J, Burke I, Brokaw N, Tilman D, Knapp A (2003) The importance of land-use legacies to ecology and conservation. Bioscience 53:77. doi:10.1641/00063568(2003)053[0077:TIOLUL]2.0.CO;2

Gehrig-Fasel J, Guisan A, Zimmermann NE (2007) Tree line shifts in the Swiss Alps: Climate change or land abandonment? J Veg Sci 18:571-582. doi:10.1111/j.1654-1103.2007.tb02571.x

Gellrich M, Baur P, Koch B, Zimmermann NE (2007) Agricultural land abandonment and natural forest re-growth in the Swiss mountains: a spatially explicit economic analysis. Agric Ecosyst Environ 118:93-108. doi:10.1016/j.agee.2006.05.001

Gimmi U, Poulter B, Wolf A, Portner H, Weber P, Bürgi M (2013) Soil carbon pools in Swiss forests show legacy effects from historic forest litter raking. Landsc Ecol 28:835-846. doi:10. 1007/s10980-012-9778-4

Greenwood S, Jump AS (2014) Consequences of treeline shifts for the diversity and function of high altitude ecosystems. Arctic Antarct Alp Res 46:829-840. doi:10.1657/1938-4246-46.4.829

GUS (2014) Prognoza ludności na lata 2014-2050. Warszawa

Hersperger AM, Burgi M (2009) Going beyond landscape change description: quantifying the importance of driving forces of landscape change in a Central Europe case study. Land Policy 26:640-648. doi:10.1016/j.landusepol.2008.08.015

Hofer G, Böni R, Herzog F, Lauber S, Seidl I (2014) AlpFUTUR: herders, home farm size and direct payments are key factors for the future of summer farming in Switzerland. In: 17th Meeting of the FAO-CIHEAM mountain pasture network, Clermont-Ferrand (FR), 24 June 2014

Huber R, Briner S, Peringer A, Lauber S, Seidl R, Widmer A, Gillet F, Buttler A, Le QB, Hirschi C (2013) Modeling socialecological feedback effects in the implementation of payments for environmental services in pasture-woodlands. Ecol Soc. doi:10.5751/es-05487-180241

Huzui EA, Abdelkader A, Patru-Stupariu I (2013) Analysing urban dynamics using multi-temporal satellite images in the case of a mountain area, Sinaia (Romania). Int J Digit Earth 6:563-579. doi:10.1080/17538947.2011.642901

Jaeger JAG, Schwick C (2014) Improving the measurement of urban sprawl: weighted urban proliferation (WUP) and its application to Switzerland. Ecol Indic 38:294-308. doi:10.1016/j.ecolind. 2013.11.022

Jagiellonian University I of $\mathrm{G}$ and SM, Warsaw University of Technology I of C and IE (2016) Forest cover mask for the Polish Carpathians late 1970s and early 1980s

Jepsen MR, Kuemmerle T, Müller D, Erb K, Verburg PH, Haberl H, Vesterager JP, Andrič M, Antrop M, Austrheim G, Björn I,
Bondeau A, Bürgi M, Bryson J, Caspar G, Cassar LF, Conrad E, Chromý P, Daugirdas V, Van Eetvelde V, Elena-Rosselló R, Gimmi U, Izakovicova Z, Jančák V, Jansson U, Kladnik D, Kozak J, Konkoly-Gyuró E, Krausmann F, Mander Ü, McDonagh J, Pärn J, Niedertscheider M, Nikodemus O, Ostapowicz K, Pérez-Soba M, Pinto-Correia T, Ribokas G, Rounsevell M, Schistou D, Schmit C, Terkenli TS, Tretvik AM, Trzepacz P, Vadineanu A, Walz A, Zhllima E, Reenberg A (2015) Transitions in European land-management regimes between 1800 and 2010. Land Policy 49:53-64. doi:10.1016/j.landusepol.2015.07. 003

Koch B, Edwards PJ, Blanckenhorn WU, Walter T, Hofer G (2015) Shrub encroachment affects the diversity of plants, butterflies, and grasshoppers on two swiss subalpine pastures. Arctic Antarct Alp Res 47:345-357. doi:10.1657/AAAR0013-093

Kolecka N, Kozak J, Kaim D, Dobosz M, Ginzler C, Psomas A (2015) Mapping secondary forest succession on abandoned agricultural land with LiDAR point clouds and terrestrial photography. Remote Sens 7:8300-8322. doi:10.3390/rs70708300

Kopainsky B, Flury C, Pedercini M, Sorg L, Gerber A (2013) Ressourceneffizienz im Dienste der Ernährungssicherheit. Teilprojekt Modellierung-Schlussbericht

Körner C, Spehn EM (2002) Mountain biodiversity. A global assessment. CRC Press, Boca Raton

Kozak J (2010) Forest cover changes and their drivers in the Polish Carpathian mountains since 1800. In: Nagendra H, Southworth J (eds) Reforesting landscapes: linking pattern and process. Springer, Dordrecht, pp 253-273

Kozak J, Szwagrzyk M (2016) Have there been forest transitions? Forest transition theory revisited in the context of the modifiable areal unit problem. Area. doi:10.1111/area.12267

Kozak J, Estreguil C, Troll M (2007) Forest cover changes in the northern Carpathians in the twentieth century: a slow transition. J Land Use Sci 2:127-146. doi:10.1080/17474230701218244

Kuemmerle T, Levers C, Erb K, Estel S, Jepsen MR, Müller D, Plutzar C, Stürck J, Verkerk PJ, Verburg PH, Reenberg A (2016) Hotspots of land use change in Europe. Environ Res Lett 11:64020

Levers C, Müller D, Erb K, Haberl H, Jepsen MR, Metzger MJ, Meyfroidt P, Plieninger T, Plutzar C, Stürck J, Verburg PH, Verkerk PJ, Kuemmerle T (2015) Archetypical patterns and trajectories of land systems in Europe. Reg Environ Change. doi:10.1007/s10113-015-0907-x

Lindemann-Matthies P, Briegel R, Schüpbach B, Junge X (2010) Aesthetic preference for a Swiss alpine landscape: the impact of different agricultural land-use with different biodiversity. Landsc Urban Plan 98:99-109. doi:10.1016/j.landurbplan.2010.07.015

MacDonald D, Crabtree JR, Wiesinger G, Dax T, Stamou N, Fleury P, Lazpita JG, Gibon A (2000) Agricultural abandonment in mountain areas of Europe: environmental consequences and policy response. J Environ Manag 59:47-69. doi:10.1006/jema. 1999.0335

Malek Ž, Boerboom L, Glade T (2015) Future forest cover change scenarios with implications for landslide risk: an example from Buzau Subcarpathians, Romania. Environ Manag 56:1228-1243. doi:10.1007/s00267-015-0577-y

Mares P, Rasin R, Pipan P (2013) Abandoned landscapes of former German settlement in the Czech Republic and in Slovenia. In: Rotherham DI (ed) Cultural severance and the environment: the ending of traditional and customary practice on commons and landscapes managed in common. Springer, Netherlands, pp 289-309

Mather AS, Fairbairn J (2000) From floods to reforestation: the forest transition in Switzerland. Environ Hist Camb 6:399-421. doi:10. 3197/096734000129342352

Munteanu C, Kuemmerle T, Boltiziar M, Butsic V, Gimmi U, Halada L, Kaim D, Kiraly G, Konkoly-Gyuro E, Kozak J, Lieskovsky J, 
Mojses M, Mueller D, Ostafin K, Ostapowicz K, Shandra O, Stych P, Walker S, Radeloff VC (2014) Forest and agricultural land change in the Carpathian region-a meta-analysis of longterm patterns and drivers of change. Land Policy 38:685-697. doi:10.1016/j.landusepol.2014.01.012

Munteanu C, Kuemmerle T, Keuler NS, Müller D, Balázs P, Dobosz M, Griffiths P, Halada L, Kaim D, Király G, Konkoly-Gyuró T, Kozak J, Lieskovsky J, Ostafin K, Ostapowicz K, Shandra O, Radeloff VC (2015) Legacies of nineteenth century land use shape contemporary forest cover. Glob Environ Change 34:83-94. doi:10.1016/j.gloenvcha.2015.06.015

Ostapowicz K, Bolliger J, Psomas A, Zimmermann NE, Bürgi M, Price B, Gimmi U, Dobosz M, Grabska E, Szwagrzyk M, Wypych A, Ustrnul Z (2015) Comparing long-term past forest cover change and its drivers in the Swiss Alps and the Polish Carpathians. In: Proceedings of the Perth III conference: Mountains of our future Earth. Perth, Scotland

Pazúr R, Lieskovský J, Feranec J, Ot'ahel' J (2014) Spatial determinants of abandonment of large-scale arable lands and managed grasslands in Slovakia during the periods of postsocialist transition and European Union accession. Appl Geogr 54:118-128. doi:10.1016/j.apgeog.2014.07.014

Pellissier L, Anzini M, Maiorano L, Dubuis A, Pottier J, Vittoz P, Guisan A (2013) Spatial predictions of land-use transitions and associated threats to biodiversity: the case of forest regrowth in mountain grasslands. Appl Veg Sci 16:227-236. doi:10.1111/j. 1654-109X.2012.01215.x

Pontius RG, Schneider LC (2001) Land-cover change model validation by an ROC method for the Ipswich watershed, Massachusetts, USA. Agric Ecosyst Environ 85:239-248. doi:10. 1016/S0167-8809(01)00187-6

Price B, Kienast F, Seidl I, Ginzler C, Verburg PH, Bolliger J (2015) Future landscapes of Switzerland: risk areas for urbanisation and land abandonment. Appl Geogr 57:32-41

Rounsevell MDA, Ewert F, Reginster I, Leemans R, Carter TR (2005) Future scenarios of European agricultural land use II. Projecting changes in cropland and grassland. Agric Ecosyst Environ 107:117-135. doi:10.1016/j.agee.2004.12.002

SFSO (2010) Szenarien zur Bevölkerungsentwicklung der Schweiz 2010-2060

SFSO (2013) Land use in Switzerland: results of the Swiss land use statistics

Stürck J, Levers C, van der Zanden EH, Schulp CJE, Verkerk PJ, Kuemmerle T, Helming J, Lotze-Campen H, Tabeau A, Popp A,
Schrammeijer E, Verburg P (2015) Simulating and delineating future land change trajectories across Europe. Reg Environ Change. doi:10.1007/s10113-015-0876-0

Swisstopo (2012) The Topographic Landscape Model TLM of Switzerland 2012 version 1.1. Federal Office of Topography swisstopo, Wabern

Szentimrey T, Bihari Z, Szalai S (2007) Comparison of geostatistical and meteorological interpolation methods (what is what?). In: Dobesch $\mathrm{H}$ et al (eds) Spatial interpolation for climate data: the use of GIS in climatology and meteorology. ISTE Ltd, London, pp 45-56

Szewczyk J, Szwagrzyk J, Muter E (2011) Tree growth and disturbance dynamics in old-growth subalpine spruce forests of the Western Carpathians. Can J For Res 41:938-944. doi:10. 1139/x11-029

Tasser E, Walde J, Tappeiner U, Teutsch A, Noggler W (2007) Landuse changes and natural reforestation in the Eastern Central Alps. Agric Ecosyst Environ 118:115-129. doi:10.1016/j.agee.2006. 05.004

Thornton PE, Running SW, White MA (1997) Generating surfaces of daily meteorological variables over large regions of complex terrain. J Hydrol 190:214-251. doi:10.1016/S00221694(96)03128-9

Tobler WR (1979) Smooth pycnophylactic interpolation for geographical regions. J Am Stat Assoc 74:519-536. doi:10.1080/ 01621459.1979 .10481647

Tokarczyk N (2013) Renaturalizacja górnoreglowych polan gorczańskich. Sylwan 157:113-121

Verburg PH, Overmars KP (2009) Combining top-down and bottomup dynamics in land use modeling: exploring the future of abandoned farmlands in Europe with the Dyna-CLUE model. Landsc Ecol 24:1167-1181. doi:10.1007/s10980-009-9355-7

Verburg PH, de Nijs TCM, van Eck JR, Visser H, de Jong K (2004a) A method to analyse neighbourhood characteristics of land use patterns. Comput Environ Urban Syst 28:667-690. doi:10.1016/ j.compenvurbsys.2003.07.001

Verburg PH, van Eck JRR, de Nijs TCM, Dijst MJ, Schot P (2004b) Determinants of land-use change patterns in the Netherlands. Environ Plan B Plan Des 31:125-150. doi:10.1068/b307

Viviroli D, Dürr HH, Messerli B, Meybeck M, Weingartner R (2007) Mountains of the world, water towers for humanity: typology, mapping, and global significance. Water Resour Res. doi:10. 1029/2006WR005653 